Dept. of Agric. Biochem.,

Fac. Agriculture, Assuit, AL-Azhar University.

\title{
ANTIFUNGAL AND ANTIMICROBIAL ACTIVITY OF CRUDE METHANOLIC EXTRACT AND ITS FRACTIONS OF JATROPHA CURCAS L., LEAVES
}

(With 3 Tables and 5 Figures)

By

\section{N.A.E. AZZAZ; R.M.I. EL-SHARKAWY* and AZHAR M. HASSAN**}

* Dept. of Botany (Plant path.), Fac. Agriculture, Assuit, AL-Azhar University.

** Animal Health Research, Animal Regional Laboratory, Assuit, Agriculture Research Center.

(Received at 11/1/2011)

تأثير المستخلص الميثانولى الخام ومكوناته لنبات الجاتروفا على الفطريات

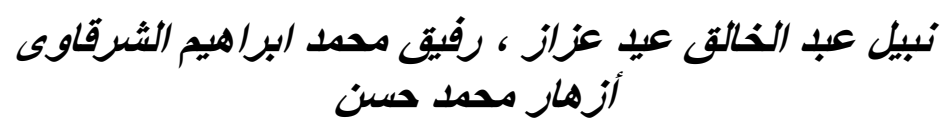

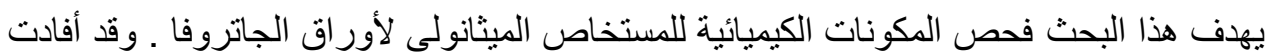

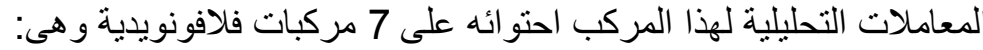

Biapigenin-(8,8")-methylene-6,6"-di-C- $\beta$-D-glucopyranoside (1), Apigenin 7- $O-\beta$-D-neohesperidoside (2), Apigenin 7- $O-\beta$-D-galactoside (3), Orientin (4), Apigenin (5), Isovitexin (6) and Vitexin (7).

Botrytis cinerea, وتم اختبار هذه المركبـات كلها من حيث تأثير هـا على نمو الفطريـات Rhizoctonia solani, Sclerotinia sclerotiorum and Fusarium solani

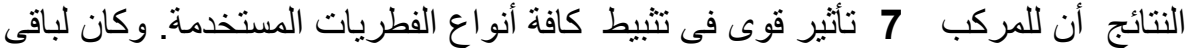

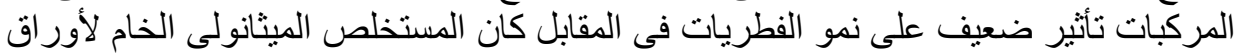

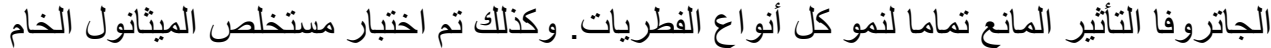

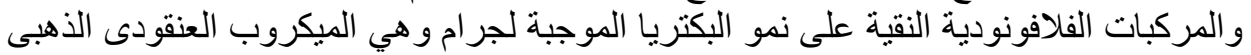

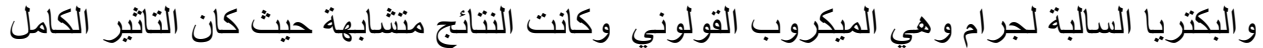

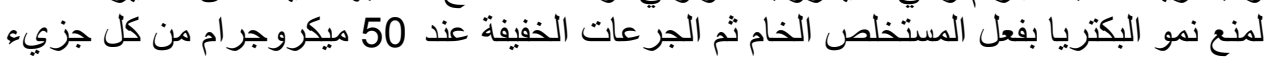

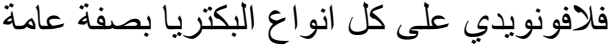

\section{SUMMARY}


In this paper the polyphenolic compounds of methanolic extract of Jatropha curcas leaves have been investigated. The analytical procedures revealed 7 flavonoid compounds: biapigenin-(8,8")-methylene-6,6"-di-C$\beta$-D-glucopyranoside (1), apigenin-7- $O$ - $\beta$-D-neohesperidoside (2), apigenin $7-O-\beta$-D-galactoside (3), orientin (4), apigenin (5), isovitexin (6) and vitexin (7). The crude methanol extract and the 7 purified compounds were tested against fungi Botrytis cinerea, Rhizoctonia solani, Sclerotinia sclerotiorum and Fusarium solani. The crude extracts absolutely inhibit the fungi growth. On the other hand, vitexin was similar to crude extract as well. The other compounds were moderate in their antifungal effects in comparison to control ones. In-vitro antimicrobial activity of the methanolic leaves extract was carried out by using the agar-well diffusion method on Gram-positive bacteria Staphylococcus aureus. The Gramnegative included Escherichia coli was compared with standard drug Streptomycin and Ampicillin.

Key words: Jatrpha, Staph. aureus, E.coli, Methanolic, Leave extract, Fractions, Fungus, Latex, antibacterial, antifungal

\section{INTRODUCTION}

Jatropha species are all members of the Euphorbiaceae family. Plants are believed to be native of tropical America but they are distributed throughout tropical and subtropical Asia and Africa. It is now widely distributed throughout the tropics occurring in south West Africa, India, Cape Verde islands, Madagascar, Java, Malaysia, Thailand, Burma and Philippines (Cano-Asseleih, 1986; Cano-Asseleih et al., 1989). Botanist Carl von Linnaeus first classified the plant in 1753; he gave it the botanical name "Jatropha curcas" from the Greek word "Jatros" meaning a "Doctor" and "Trophe" meaning "Nutrition" (Agnote, 1998; Dorth, 2003). Jatropha is commonly known as Physic nut or purging nut but in different countries and in different languages it has different common or vernacular names: Physic nut, Purging nut (English); Pourghere, Pignon d'Inde (French); Purgier-nub, Brechnab (German); Pinoncillo (Mexico); Coquillo, Tempate (Costa Rica); Tartago (Puerto Rico); Mundubi-assu (Brazil); Pinol (Peru); Pinon (Guatemala); Bagbherenda, Jangliarandi, (Hindi); Sabudam (Thailand); Tubangbakod (Philippines), Jarak budge (Indonesia); Bagani (Cote D' Ivoire); Tabanani (Senegal); Butuje, Lapalapa (Nigeria); Makaen (Tanzania); Purgeer boontjie (South Africa); Dand barri, Habel melak 
(Arab); Yu-la-Tzu (Chinese); Fagiala d' India (Italian) and Purgueira (Portuguese) (Heller, 1996; Becker and Francis, 2003). Jatropha curcas or Physic nut is a multipurpose and drought resistant, perennial plant (Jones and Miller 1992; Openshaw 1986). It can be grown in low to high rainfall areas either in the farm as a commercial crop or on the boundaries as a hedge to protect fields from grazing animals and to prevent erosion (Henning 1996; Gübitz et al., 1999). The leaves are remedy for jaundice, applied by rectal injection (Okujagu et al., 2006). The by-products are press cake; good organic fertilizer and oil contains also insecticides (Openshaw, 1986). Traditionally it is used to cure diseases like cancer, piles, snakes bites, paralysis and dropsy (Okujagu et al., 2006). Medically, the heated leaves are placed on the breast as a lactagogue in Guatemala (Morton, 1981). The leaves are regarded as antiparasitic and applied in scabies. They are also used as rubefacients in paralysis, in rheumatism and also applied to tumors (Perry, 1980; Duke, Atchley 1984). J curcas leaves extract is a component of formulation orally used in the treatment of malaria (Ankrah et al., 2003). These suggest that the plant leaves may not be as toxic as the seeds. $J$ curcas leaves possess antiseptic, purgative, cicatrizant effects (Faria et al., 2006). Phytochemical analysis of $J$ curcas revealed the presence of alkaloids, glycosides, saponins, tannins, flavonoids, resins, sterols, terpenoids and carbohydrates in the methanol extract that have implicated in the antimicrobial activities as well as free radical scavenging activities of some plants. The leaves also demonstrated antioxidant and haemostatic activities as well as acceleration of wound healing and antimicrobial activity against microbial wound contamination (Okoli et al., 2008). Flavonoids have free radical scavenging and antioxidation properties, which are useful for their pharmacological activities including anticancer and anti-aging properties. Many flavonoids show antibacterial, antiviral and antifungal activities (Ng et al., 1996; Sharma 2006). The studies of chemistry, biochemistry and pharmacological properties of flavonoids may be important (Cody et al., 1984; Cody et al., 1989; Havsteen 2002; Winkel-Shirely 2002). They also possess antimicrobial properties (Hernandez et al., 2000; Sohn et al., 2004). Previous works have shown that many Jatropha species possess antimicrobial activity (Aiyelaagbe et al., 2000 and Aiyelaagbe et al., 2007). Several studies have confirmed the antimicrobial efficacy of different Jatropha species; however, there is insufficient information regarding the antimicrobial activities of $J$. curcas. The aim of this work is the evaluation of Jatropha curcas L. leaves constituents and its antifungal and antibacterial activities. 


\section{MATERIALS and METHODS}

\section{Sample Preparation:}

Jatropha curcas L. leaves were collected at Sept. 20, 2009 from Jatropha curcas plants which planted on March 15, 2009 at Faculty of Agriculture Farm, AL-Azhar University, Assiut branch, Assiut, Egypt. Leaves were air dried at laboratory of Chemistry Department conditions for one month. The leaves were crushed and grinded to fine powder by plant grinder.

\section{Extraction and Fractionation:}

One kilogram of the fine leaves powder was macerated in 4 liters of $80 \%$ methanol for 24 hours at room temperature and extracted again by $3 \mathrm{~L}$ $\mathrm{x} 3$ times of $80 \%$ methanol at room temperature. The extracts were combined and concentrated by rotary evaporator under reduced pressure at low temperature. The residue (95 g) was defatted by ( $3 \mathrm{~L} \mathrm{x} 3$ times) petroleum ether (bp. $40-60^{\circ} \mathrm{C}$ ). The petroleum ether fraction (oil) was discarded. Crude methanol extract were tested against fungi. The defatted residue $(89 \mathrm{~g})$ was preliminary fractionated on silica gel column $(3 \mathrm{x} 70$ $\mathrm{cm}$ ) using a step gradient of solvent system 1 (Hexane: EtOAc, 100:0, 0: $100 \mathrm{v} / \mathrm{v}$ ) then, solvent system 2 (methanol: $\mathrm{H}_{2} \mathrm{O}, 100: 0,0: 100 \mathrm{v} / \mathrm{v}$ ) was used for elution to give 35 fractions. Then, collected and divided by U.V. light into seven (I-VII) major collective fractions. Some of other fractions are still unknown. The homogeneity of the compounds was purified by silica gel TLC plates. These fractions were subjected to further purification by column chromatography each as below. Fraction I (180mg) was fractionated by Sephadex $\mathrm{LH}_{20}$ column chromatography and eluted by methanol. Fraction II chromatographed similar and gave pure compound 2 (130mg). Carboxy methyl cellulose column of fraction III further purified using \{Butanol: isopropanol: $\mathrm{H}_{2} \mathrm{O}, 4: 1: 5 \mathrm{v} / \mathrm{v}$, : methanol (50:50)\} as eluent to give purified $28 \mathrm{mg}$ of compound 3 and $25 \mathrm{mg}$ of compound 4 . Fractions IV, V and VI exposed to Sephadex $\mathrm{LH}_{20}$ column chromatography with methanol: water as eluent solvent system to gain 30mg of pure compound $5,14 \mathrm{mg}$ of compound 6 and $11 \mathrm{mg}$ of compound 7. Fraction VII eluted by butanol: isopropanol: water to give compound 1. All of these fractions and others (unknowns) were subjected to analysis by $\mathrm{H}^{1}$-NMR and GC-MS instruments as follows: ${ }^{1} \mathrm{H}-\mathrm{NMR}$ data were measured in $\mathrm{CDCl}_{3}$ or DMSO$d_{6}$ on a Varian XL 200, $300 \mathrm{MHz}$ instruments using TMS as internal standard. Chemical shifts were reported in ppm $(\delta)$ downfield from internal TMS and coupling constants are expressed in hertz. Mass spectra were recorded on GC-MS QP-1000 EX. Shimadzu Instrument consisted of a Varian 3400 gas chromatography equipped with a fused-silica column 
( $30 \mathrm{~m} \times 0.25 \mathrm{~mm}$, film thickness $0.25 \mathrm{~mm}$ ). The operating conditions were: oven temperature $40-210{ }^{\circ} \mathrm{C}$ with the rate of $5^{\circ} \mathrm{C} / \mathrm{min}$; injector mode: split injection; with the carrier gas, He; flow rate $1 \mathrm{ml} / \mathrm{min}$; ionization current, $750 \mathrm{~mA}$; scan range, $40-300 \mu$., Faculty of Science, Cairo University.

\section{Fungal Experiment:}

Preparation of crude antibiotic discs: sterile Whatman No. 1 paper was punched into $5 \mathrm{~mm}$ diameter disc sizes. The Whatman discs were placed in Mac Cartney bottles and sterilized in an autoclave at $120^{\circ} \mathrm{C}$ for $15 \mathrm{~min}$. the bottles was transferred into a hot air oven at $60^{\circ} \mathrm{C}$ to dry for $30 \mathrm{~min}$. an aqueous extract of leaves $(1.0 \mathrm{ml})$ was transferred into a sterile bottle containing sterile discs. The sterile crude discs were allows to soak in extract of each fraction (I-VII) for $4 \mathrm{hr}$ for proper absorption, after which they removed and allowed to dry. The control disc was immersed in distilled water instead of fractions (Cheesebrough, 2000). Potato dextrose agar (PDA) media (200g of potato, 20g of dextrose and $20 \mathrm{~g}$ of agar) was thawed at $45^{\circ} \mathrm{C}$ and poured onto $9 \mathrm{~cm}$ Petri dishes. After cooling at room temperature, the dishes were fertilized with uniform discs of the fungus (Barnette and Hunter, 1972). Four tested fungi genus; Botrytis cinerea, Rhizoctonia solani, Sclerotinia sclerotiorum and Fusarium solani against the crude extract and the seven purified fractions. The experiment was made in triplicate for each fraction. The dishes were incubated for 7 days at $25^{\circ} \mathrm{C} \pm 3$, then, the inhibition zone was measured.

\section{Bacterial Experiment:}

\section{Preparation of microorganism for the experiment}

The following typed cultures and locally isolated organisms obtained from culture collectionlof lab Ministry of heath were used for the experiment. These bacteria isolates include Gram-positive Staphylococcus aureus (NCIB 8588). The Gram-negative include Escherichia coli (NCIB 86). The bacterial isolates were first subcultured in a nutrient broth (Oxoid) and incubated at $37^{\circ} \mathrm{C}$ for $18 \mathrm{~h}$.

\section{Antibacterial activity}

The antibacterial activity of the crude extracts was determined in accordance with the agar-well diffusion method described by Irobi et al. (1994). The bacterial isolates were first grown in a nutrient broth for $18 \mathrm{~h}$ before use and standardized to $0.5 \mathrm{McFarland}$ standards $\left(106 \mathrm{cfu} / \mathrm{ml}^{-1}\right)$. Two hundred microliter of the standardized cell suspensions were spread on a Mueller-Hinton agar (Oxoid). Wells were then bored into the agar using a sterile $6 \mathrm{~mm}$ diameter cork borer. Approximately $100 \mu \mathrm{l}$ of the crude extract at $10 \mathrm{mg} / \mathrm{ml}^{-1}$ were introduced into the wells, allowed to stand at room temperature for about $2 \mathrm{~h}$ and then incubated at $37^{\circ} \mathrm{C}$. 
Controls were set up in parallel using the solvents that were used to reconstitute the extract. The plates were observed for zones of inhibition after $24 \mathrm{~h}$. The effects were compared with those of streptomycin and ampicilin at a concentration of $1 \mathrm{mg} / \mathrm{ml}$ and $10 \mu \mathrm{g} / \mathrm{ml}^{-1}$ respectively.

\section{Minimum inhibitory concentration (MIC)}

The estimation of MIC of the crude extracts was carried out using the method of Akinpelu and Kolawole (2004). Two-fold dilutions of the crude extract was prepared and $2 \mathrm{ml}$ aliquots of different concentrations of the solution were added to $18 \mathrm{ml}$ of pre-sterilized molten nutrient agar at $40^{\circ} \mathrm{C}$ to give final concentration regimes of 0.050 and $10 \mathrm{mg} / \mathrm{ml}$. The medium was then poured into sterile Petri dishes and allowed to set. The surface of the medium was allowed to dry under laminar flow before streaking with $18 \mathrm{~h}$ old bacterial cultures. The plates were later incubated at $37^{\circ} \mathrm{C}$ for $24 \mathrm{~h}$ for up to $72 \mathrm{~h}$ for bacteria after which they were examined for the presence or absence of growth. The MIC was taken as the lowest concentration that prevented the growth of the test microorganism.

\section{Minimum bactericidal concentration (MBC)}

The MBC of the plant extracts was determined by a modification of the method of Spencer and Spencer (2004). Samples were taken from plates with no visible growth in the MIC assay and subcultured on freshly prepared nutrient agar plates and incubated at $37^{\circ} \mathrm{C}$ for $48 \mathrm{~h}$. The $\mathrm{MBC}$ was taken as the concentration of the extract that did not show any growth on a new set of agar plates.

\section{RESULTS}

Table 1: Antifungal activity of $J$. curcas crude methanolic extract and its flavonoids.

\begin{tabular}{|c|c|c|c|c|}
\hline \multirow{2}{*}{ Fraction No. } & \multicolumn{4}{|c|}{ Fungi species } \\
\cline { 2 - 5 } & B. cinerea & $R$. solani & S. sclerotiorum & $F$. solani \\
\hline I & 4.6 & 6.1 & 4.8 & 5.8 \\
\hline II & 5.2 & 6.0 & 5.0 & 6.2 \\
\hline III & 8.2 & 8.2 & 8.2 & 8.8 \\
\hline IV & 7.6 & 9.0 & 8.4 & 9.0 \\
\hline V & 4.9 & 6.5 & 5.4 & 6.3 \\
\hline VI & 5.2 & 5.6 & 4.8 & 5.8 \\
\hline VII & 0.9 & 1.9 & 0.7 & 1.7 \\
\hline Crude Ext. & 0.0 & 0.0 & 0.0 & 0.0 \\
\hline control & 9.0 & 9.0 & 9.0 & 9.0 \\
\hline
\end{tabular}


Table 2: Antibacterial activity of jatropha leaves crude mathanolic extract and its fractions.

\begin{tabular}{|c|c|c|c|c|c|}
\hline \multirow{3}{*}{ Organism } & \multirow{3}{*}{ Fraction } & \multicolumn{4}{|c|}{ Concentration $(\mu \mathrm{g} \backslash \mathrm{ml})$} \\
\hline & & 50 & 100 & 150 & 200 \\
\hline & & \multicolumn{4}{|c|}{ Inhibition Zone (mm) } \\
\hline \multirow{10}{*}{ 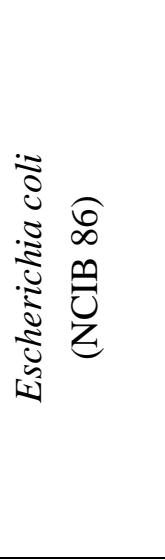 } & Crude & 0 & 0 & 0 & 0 \\
\hline & 1 & 8.25 & 11.50 & 13.00 & 16.75 \\
\hline & 2 & 6.75 & 8.75 & 12.50 & 16.75 \\
\hline & 3 & 7.00 & 9.25 & 12.00 & 16.00 \\
\hline & 4 & 5.75 & 8.75 & 13.00 & 15.25 \\
\hline & 5 & 8.00 & 3.66 & 13.00 & 16.66 \\
\hline & 6 & 8.75 & 11.00 & 13.33 & 16.66 \\
\hline & 7 & 7.00 & 9.66 & 12.00 & 15.33 \\
\hline & Strept. & 0 & 0 & 0 & 0 \\
\hline & Amp. & 18 & 18 & 18 & 18 \\
\hline \multirow{10}{*}{ 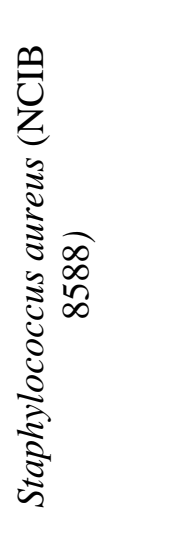 } & Crude & 0 & 0 & 0 & 0 \\
\hline & 1 & 9.25 & 12.00 & 15.25 & 16.50 \\
\hline & 2 & 8.50 & 10.75 & 12.25 & 15.00 \\
\hline & 3 & 8.50 & 11.50 & 14.00 & 16.25 \\
\hline & 4 & 9.00 & 12.25 & 14.75 & 16.75 \\
\hline & 5 & 8.33 & 12.00 & 15.33 & 17.00 \\
\hline & 6 & 9.00 & 11.25 & 14.00 & 16.00 \\
\hline & 7 & 7.33 & 10.00 & 11.66 & 12.66 \\
\hline & Strept. & 22 & 22 & 22 & 22 \\
\hline & Amp. & 0 & 0 & 0 & 0 \\
\hline
\end{tabular}

Table 3: Minimum inhibitory concentration (MIC) and minimum bactericidal activity (MBC)

\begin{tabular}{|c|c|c|}
\hline Test organisms & $\begin{array}{c}\text { The minimum inhibitory } \\
\text { concentration (MIC) }\end{array}$ & $\begin{array}{c}\text { The minimum bactericidal } \\
\text { activity (MBC) }\end{array}$ \\
\hline $\begin{array}{c}\text { Escherichia coli } \\
\text { (NCIB 86) }\end{array}$ & $50 \mu \mathrm{g} / \mathrm{ml}$ & $15.33 \mathrm{~mm}$. \\
\hline $\begin{array}{c}\text { Staphylococcus } \\
\text { aureus(NCIB } 8588)\end{array}$ & $100 \mu \mathrm{g} / \mathrm{ml}$ & $7 \mathrm{~mm}$. \\
\hline
\end{tabular}




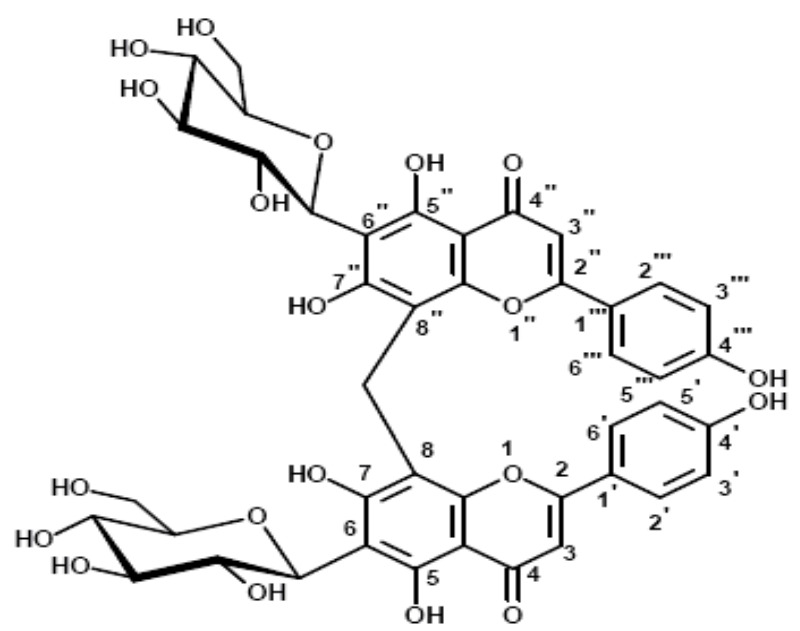

Biapigenin-(8,8")-methylene-6,6"'-di-C- $\beta$-D-glucopyranoside (1)

(Fig. 1)<smiles>[R2]c1cc(-c2cc(=O)c3c(O)c([R])c([R20])c([Y])c3o2)ccc1O</smiles>

Apigenin-7-O $\boldsymbol{\beta}$-D-neohesperidoside (2) $R^{1}=R^{3}=R^{4}=H, R^{2}=\beta$-D-neohesperidoside Apigenin 7-O- $\beta$-D-galactoside (3) $\mathrm{R}^{1}=\mathrm{R}^{3}=\mathrm{R}^{4}=\mathrm{H}, \mathrm{R}^{2}=\beta$-D-galactopyranoside Orientin (4) $\mathrm{R}^{1}=\mathrm{R}^{2}=\mathrm{H}, \mathrm{R}^{3}=\beta$-D-glucopyranoside, $\mathrm{R}^{3}=\mathrm{OH}$ (Fig. 2)<smiles>O=c1c(O)c(-c2ccc(O)c(O)c2)oc2cc(O)cc(O)c12</smiles>

Apigenin (5)

(Fig. 3) 
<smiles>O=c1cc(-c2ccc(O)cc2)oc2cc(O)c([C@@H]3O[C@H](CO)[C@@H](O)[C@H](O)[C@H]3O)c(O)c12</smiles>

\section{Isovitexin (6)}

(Fig. 4)

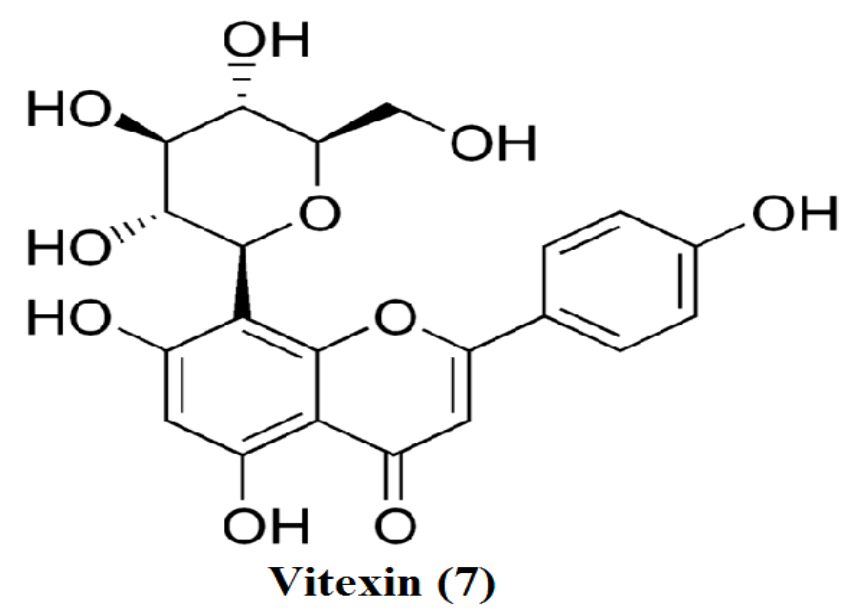

(Fig. 5)

\section{DISCUSSION}

The obtained analytical data revealed that the major polyphenolic compounds are flavonoids and biflavonaids. The identified compounds were authenticated according to its $\mathrm{H}^{1-} \mathrm{NMR}$ and GC/MS analytical data which matched to computer library. Compounds are biapigenin- $\left(8,8^{\prime \prime}\right)$ methylene-6,6"-di-C- $\beta$-D-glucopyranoside (1), apigenin $\quad 7-O-\beta$-Dneohesperidoside (2), apigenin 7- $O-\beta$-D-galactoside (3), orientin (4), apigenin (5), isovitexin (6) and vitexin (7). Table (1) shows the obtained results. Crude methanolic extract showed absolutely inhibition zones and have zero growth up to one month. While, the purified fractions showed a variance in growth zones from $0.95 \mathrm{~cm}$ to $9 \mathrm{~cm}$ after one week since 
inoculation. Compound VII (vitexin) seems to be the most antifungal compounds. The compounds I, II, V and VI have moderate effect as fungicides. On the other hand, compounds III and IV showed no significant inhibition zone of fungi species (Sharma 2006 and $\mathrm{Ng}$ et al., 1996). These polyphenolic compounds have health benefits. So J. curcas leaves consider as important source of these compounds and not be toxic as the seeds or in the native J. curcas countries (Masaoud et al., 1995; Okuyama et al., 1996; Aiyelaagbe et al., 1998). The obtained data is agreed with that of Abd-Alla et al. (2010) on the same plant species.

\section{Antibacterial activity}

Data in Table (2) reveals that methanolic leaves extract possess potential antimicrobial activity. The obtained results indicates that the methanol leaf extract had shown maximum zone of inhibition at $200 \mu \mathrm{g} / \mathrm{ml}$ on the 7 flavonoid compounds. All extracts of the plant tested showed varying degree of antibacterial activities against the test bacterial; Staphylococcus aureus and on Escherichia coli species. The antibacterial activities of the methanolic extracts compared favorably with that of two standard antibiotics (streptomycin and ampicillin) and appeared to have a broad spectrum according to its activities on gram reaction. The inhibition zone of Staphylococcus aureus and Escherichia coli was compared to the minimum inhibitory concentration (MIC) of the methanolic fractions (I-VII) ranged between $100 \mu \mathrm{g} / \mathrm{ml}$ and $50 \mu \mathrm{g} / \mathrm{ml}$ for Gram positive and negative bacteria, respectively. The minimum bactericidal activity (MBC) of the extract for Gram positive and negative bacteria ranged between 7-15.33 mm. (Table 3) Generally, the methanol extract was more active. This may be attributed to the presence of soluble phenolic and polyphenolic compounds (Kowalski and Kedzia, 2007). The inhibitory effect of the extract of $J$. curcas against pathogenic bacterial strains can introduce the plant as a potential candidate for drug development for the treatment of ailments caused by these pathogens investigated in this study is in agreement with (Koduru et al., 2006; Aliero et al., 2006; Ashafa et al., 2008; Aiyegoro et al., 2008). Mujumdar et al. (2001) also reported that the crude methanol extract from the root of $J$. curcas exhibited anti-diarrhea activity in mice through the inhibition of prostaglandin biosynthesis and the reduction of osmotic pressure. Recently, Aiyelaagbe et al. (2007) reported that the presence of some secondary metabolites in the root extract of $J$. curcas inhibited some microorganisms isolated from sexually transmitted infections. In future, it seems that this plant still need some research on its chemical composition to be evaluated under Egyptian conditions. 


\section{REFERENCES}

Abd-Alla I. Howaida; Fatma A. Moharram; Ahmed H. Gaara and Mounir M. El-Safty (2010): Phytoconstituents of Jatropha curcas L. Leaves and their Immunomodulatory Activity on Humoral and CellMediated Immune Response in Chicks. Z. Naturforsch. 64 c, 495-501.

Agnote (1998): Physic Nut, 583, No-F-70, Agdex No: 643, April 1998. Aiyegoro, O.A.; Akinpelu, D.A.; Afolayan, A.J. and Okoh, A.I. (2008): Antibacterial activities of crude stem bark extracts of Distemonanthus benthamianus Baill; J. Biol. Sci. 8(2): 356-361.

Aiyelaagbe, O.O.; Gloer, J.B.; Adesogan, E.K. and Ekundayo, O. (1998): Chemical constituents of Jatropha podagrica. Fitoterapia 64: 381-382.

Aiyelaagbe, O.O.; Adesogan, E.K.; Ekunday, O. and Adeniyi, B.A. (2000): The antimicrobial activity of roots of Jateopha podagrica Hook. Phytother. Res. 14: 60-62

Aiyelaagbe, O.O.; Adeniyi, B.A.; Fatunsin, O.F. and Arimah, B.D. (2007): In vitro antimicrobial activity and photochemical analysis of Jatropha curcas roots Intern. J. Pharmacol. 3(1): 106-110.

Akinpelu, D.A. and Kolawole, D.O. (2004): Phytochemical and antimicrobial activity of leaf extract of Piliostigma thonningii (Schum.). Sci. Focus J. 7: 64-70.

Aliero, A.A.; Grierson, D.S. and Afolayan, A.J. (2006): Antifungal activity of Solanum pseudocapisum Res. J. Bot. 1: 129-133.

Ankrah, N.; Nyarko, A.K.; Addo, P.G.A.; Ofosuhene, M.; Dzokoto, C.; Marley, E.; Addae, M.M. and Ekuban, F.A. (2003): Phytother. Rcs. 17(6j: 6977.31.

Ashafa, A.O.T.; Grierson, D.S. and Afolayan, A.J. (2008): Antimicrobial activity of extract from Felicia muricata Thunb J. Biol. Sci. 8(6): 1062-1066.

Barnette, H.L. and Hunter, B.B. (1972): Illustrated genera of imperfect fungi printed in U.S.A. $3^{\text {rd }}$ edition.

Becker, K. and Francis, G. (2003): Jatropha plantations on degraded land. Workgroup Multifunctional Plants, University of Hohenheim, Stutgart, Germany.

Cano-Asseleih, L.M. (1986): Chemical investigation of Jatropha curcas L. seeds. Ph. D. Thesis, University of London, U. K. 290 pp. 
Cano-Asseleih, L.M.; Plumbly, K.A. and Hylands, P.J. (1989): Food Biochem. 13: 1-20.

Cheesebrough, M. (2000): District Laboratory Practice in Tropical Countries. Part 1, First Edition. Press Syndicate of the University of Cambridge. pp: 132-143

Cody, V.; Middleton, E.; Harborne, J.B.; Beretz, A. and Alan, R. Liss (1989): Plant flavonoids in biology and medicine II. Biochemical, cellular and medicinal properties: Inc, New York, 1988, Book Review, Phytochem, 28: 22-26.

Cody, V.; Middleton, E.; Harborne, J.B.; Beretz, A. and Alan, R. Liss (1984): Plant flavonoids in biology and medicine: biochemical, pharmacological and structure activity relationships, Miscellaneous, Biochimie, 66: 19-26.

Dorth jocker, (2003): DFSC, Environment Africa, Seed leaflet No: 83, August.

Duke, J.A. and Atchley, A.A. (1984): Proximate analysis. In: Christie, BR (ed.). The Handbook of Plant Science in Agriculture. CRC Press, Inc., Boca Raton, FL.

Faria, M.H.G.; Carvalho, T.G.; Rabenhorst, S.H.B.; Sidrim, J.J.C. and Moraes-Filho, M.O. (2006): Cytotoxic and antifungal properties of medicinal plants from Ceará, Brazil. Braz. J. Biol., 66 (4): 1133-1135.

Gübitz, G.M.; Mittelbach, M. and Trabi, M. (1999): "Exploitation of the tropical oil seed plant Jatropha curcas L," Bioresource Technology, 67: 73-82.

Havsteen, B.H. (2002): The biochemistry and medical significance of flavonoids. Review article, Pharmacol Therapeut, 96: 67-202.

Heller, J. (1996): Physic nut (Jatropha curcas L.). Promoting the conservation and use ofunderutilized and neglected crops 1. Institute of Plant Genetics and Crop Plant Research, Germany, and International Plant Genetic Resources Institute, Rome.

Henning, R. (1996): The Jatropha curcas protection in Mali. Rothkreuzu, D-88138 Weissenber. Germany

Hernandez, N.E.; Tereschuk, M.L. and Abdala, L.R. (2000): Antimicrobial activity of flavonoids in medicinal plants from Tafi del Valle (Turuman argentina), J. Ethnopharmacol., 73: 317-322.

Irobi, O.N.; Moo-Young, M.; Anderson, W.A. and Daramola, S.O. (1994): Antimicrobial activity of the bark of Bridelia ferruginea (Euphorbiaceae). Intern. J. Pharmacog. 34: 87-90. 
Jones, N. and Miller, J.H. (1992): Jatropha curcas: A multipurpose species for problematic sites, The World Bank Washing ton D.C USA.

Koduru, S.; Grierson, D.S. and Afolayan, A.J. (2006): Antimicrobial activity of Solanum aculeastrum (Solanaceae). Pharamacol. Biol. 44: 284-286.

Kowalski, R. and Kedzia, B. (2007): Antibacterial activity of Silphium perfoliatum extracts. Pharm. Biol. 45: 495-500 Methods and Protocols. Human Press Inc. New Jersey. pp. 325-327

Masaoud, I.M.; Ripperger, H.; Porzel, A. and Adam, G. (1995): Flavonol glycosides from Jatropha variegate. Z. Prakt. Chem./Chem.-Ztg. 337: 43-45.

Morton, J.F. (1981): Atlas of Medicinal Plants of Middle America: Bahamas to Yucatan. Charles C. Thomas, Springfield, USA.

Mujumdar, A.M.; Misar, A.V.; Salaskar, M.V. and Upadhye, A.S. (2001): Antidiarrhoeal effect of an isolated fraction (JC) of Jatropha curcas roots in mice. J. Nat. Remedies, 1: 89-93.

Ng, T.B.; Ling, J.M.L.; Wang, Z.T.; Cai, J.N. and Xu, G.J. (1996): Examination of coumarins, flavonoids and polysaccharopeptides for antibacterial activity, Gen Pharmac, 27: 1237-1240.

Okoli, O. Charles; Peter A. Akah; Adaobi C. Ezike; Sunday Udegbunam; Sylvester C. Nworu and Theophine C. Okoye (2008): Ethnobiology and Pharmacology of Jatropha Curcas L, Ethnopharmacology, 8:101-1 25

Okujagu, T.F.; Etatuvie, S.O.; Eze, I.; Jimoh, B.; Nweke, C. and Mbaoji, C. (2006): Medicinal Plants of Nigeria; South-west Nigeria. In collaboration with Lagos state Traditional Medicine Board and Botany Department, University of Lagos.1st ed 1: 20.

Okuyama, E.; Okamoto, Y.; Yamazaki, M. and Satake, M. (1996): Pharmacologically active components of a Peruvian medicinal plant, Huanarpo (Jatropha cilliata). Chem. Pharm. Bull. 44: 333-336.

Openshaw, K. (1986): Concepts and Methods for collecting and compilling statistics in Biomas used as Energy. UN statistical office New York USA.

Perry, L.M. (1980): Medicinal Plants of East and Southeast Asia. MTT Press. Cambridge. 
Sharma, D.K. (2006): Pharmacological properties of flavonoids including flavonolignans- Integration of petrocrops with drug development from plants. Journal of Scientific \& Industerial Research 65: 477-484.

Sohn, H.Y.; Son, K.H.; Kiwan, C.S.; Kwon, C.S. and Kang, S.S. (2004): Antimicrobial and cytotoxic activity of 18 prenylated flavonoids isolated from medicinal plants: Morus alba L, Morus mangolica Schneider, Broussnetia papyrifera (L.) Vent, Sophora flavescens A and Echinosphora korensis Nakai, Phytomedicine, 11: 666-672.

Spencer, A.L.R. and Spencer, J.F.T. (2004): Public Health Microbiology. Winkel-Shirely, B. (2002): Biosynthesis of flavonoids and effect of stress. Review article, Curr Opinion in plant Biol, 5: 218-223. 